\title{
Protein restriction during early development enhances insulin responsiveness but selectively impairs sensitivity to insulin at low concentrations in white adipose tissue during a later pregnancy
}

\author{
M. J. Holness*, L. G. D. Fryer and M. C. Sugden \\ Molecular and Cellular Biology, Division of Biomedical Science, St Bartholomew's and \\ the Royal London School of Medicine and Dentistry, Queen Mary and Westfield College, London E1 4NS, UK
}

(Received 31 July 1998 - Revised 2 December 1998 - Accepted 25 January 1999)

\begin{abstract}
Poor early nutrition may elicit long-term detrimental effects on adult health, including susceptibility to non-insulin-dependent diabetes mellitus. We investigated the impact of moderate maternal protein restriction during pregnancy and lactation on the action of insulin on adipocyte glucose uptake in female offspring during their own pregnancies. Offspring of dams provided with diets containing either $200 \mathrm{~g}$ protein $/ \mathrm{kg}$ or $80 \mathrm{~g}$ protein $/ \mathrm{kg}$ during pregnancy and lactation (termed C and EPR groups respectively) were weaned on to $200 \mathrm{~g}$ protein $/ \mathrm{kg}$ diet at $24 \mathrm{~d}$ of age. At 9-12 weeks of age both groups were time-mated and studied at day 19 of gestation. Rates of glucose utilization (assessed using the 2-deoxy-D-[1- $\left.{ }^{3} \mathrm{H}\right]$ glucose technique) measured in five distinct adipose tissue depots (parametrial (PM), mesenteric (MES), perirenal (PR), subcutaneous (SC), interscapular (IS)) in vivo in the post-absorptive state were consistently lower in earlyprotein-restricted (EPR) pregnant rats compared with control (C) pregnant rats. In C pregnant rats, insulin significantly increased glucose utilization only in the IS depot. In contrast, significantly increased glucose utilization rates in response to hyperinsulinaemia were evident in all five adipose-tissue depots of the EPR pregnant group. Consequently, glucose utilization rates in PM and SC depots during hyperinsulinaemia were significantly higher in EPR pregnant rats compared with $\mathrm{C}$ pregnant rats. Adipocytes were isolated from PM and MES depots to determine whether altered responses to insulin in vivo were retained in vitro. Rates of insulinstimulated glucose uptake at sub-maximal $(15 \mu \mathrm{U} / \mathrm{ml})$ and maximal $(15 \mathrm{mU} / \mathrm{ml})$ insulin concentrations were significantly higher in both MES and PM adipocytes from EPR pregnant rats, but the sensitivity of glucose uptake to insulin at low concentrations was blunted compared with adipocytes from $\mathrm{C}$ pregnant rats. The results demonstrate that early protein restriction enhances the capacity for adipocyte glucose uptake at high insulin concentrations, but dampens the response to insulin at low physiological concentrations.
\end{abstract}

Maternal diet: Adipocytes: Low-protein diet

Epidemiological studies in man have identified an association between low birth weight and weight at 1 year and the development of hypertension (Barker et al. 1992) and impaired glucoregulatory control in later life, particularly when the diet imposes a secretory challenge on the endocrine pancreas (Hales, 1997). Studies in rats have shown that the intrauterine and early neonatal growth of the offspring is adversely affected by moderate protein restriction of the dam (a diet containing $80 \mathrm{~g}$ protein $/ \mathrm{kg}$, compared with $200 \mathrm{~g}$ protein $/ \mathrm{kg}$ ), even when the total energy intake is maintained by supplementary carbohydrate (Dahri et al. 1991; Holness, 1996b; Holness \& Sugden, 1996; Holness et al. 1998). If rats are subsequently transferred to a diet containing the normal amount of protein at weaning, the offspring previously exposed to moderate protein restriction gain weight at a greater rate compared with controls. Thus, differences in body weights are minimized by adulthood (Holness, 1996b; Holness et al. 1998). Nevertheless, offspring that have experienced early growth retardation retain persistent abnormalities in liver enzyme complement (Desai et al. 1997), are prone to the development of hypertension (Langley-Evans et al. 1996) and altered glucose tolerance, either impaired (Dahri et al. 1991) or enhanced (Holness, 1996b; Shepherd, 1997). In addition, epididymal adipocytes isolated from male rats that have experienced early growth retardation as a consequence of protein restriction of their mothers during pregnancy and lactation exhibit significantly higher rates of glucose uptake, both in the basal state and 
during stimulation with insulin at a high concentration (Ozanne et al. 1997). The latter effect has been suggested to be related to higher expression of the insulin receptor and insulin-receptor-substrate 1-associated phosphatidylinositol 3-kinase activity compared with controls (Ozanne et al. 1997).

Pregnancy imposes an increased insulin secretory demand both by virtue of an altered set point for insulin secretion in response to hyperglycaemia (Nolan \& Proietto, 1996) and because peripheral insulin resistance necessitates compensatory insulin secretion to permit glucose clearance (reviewed by Sugden \& Holness, 1998). The storage and mobilization of adipose-tissue triacylglycerol is of critical importance in the maternal adaptations to pregnancy (reviewed by Sugden \& Holness, 1998) and increased use of lipid-derived fuels may, at least in part, 'spare' glucose for use by the fetus (Holness \& Sugden, 1997). A study of the persistent effects of early growth retardation induced by early protein deprivation on insulin action during a subsequent pregnancy revealed that glucose utilization during physiological hyperinsulinaemia was specifically impaired in fast-twitch muscles (Holness \& Sugden, 1996). Adipose tissue was not studied in detail; however, a trend towards decreased glucose utilization by interscapular white adipose tissue of the rats that had experienced early growth retardation was evident in the post-absorptive state whereas insulin-stimulated glucose utilization tended to be higher. Considerable regional variations exist in the metabolic characteristics of white adipose tissue. The mesenteric (visceral) and retroperitoneal depots may be particularly important, and relatively superficial adipose tissue depots (such as interscapular adipose tissue) unimportant, for lipid storage after a meal (West et al. 1989). Visceral adipocytes have higher lipolytic capacities than cells from the subcutaneous depot (Ostman et al. 1979; Bolinder et al. 1983; Engfeldt \& Arner, 1988); furthermore, adipocytes from the intra-abdominal depots may be less responsive to the antilipolytic actions of insulin (Ostman et al. 1979; Bolinder et al. 1983). The accumulation of visceral fat has been associated with a decrease in insulin sensitivity, as measured by hyperinsulinaemic clamp (Peiris et al. 1988) and leg balance studies (Colberg et al. 1995), and changes in visceral fat contribute significantly to variability in insulin sensitivity in heterogeneous populations of men (Coon et al. 1992) and women (Carey et al. 1996). The breakdown of stored triacylglycerol in visceral adipose tissue may exert a major influence on non-esterified fatty acid flux to the liver (Bjorntorp, 1990), and it has been hypothesized that 'portal' effects of non-esterified fatty acids and glycerol released by increased mesenteric fat tissue may cause hepatic insulin resistance (Bjorntorp, 1990). It may, therefore, not necessarily be valid to extrapolate results obtained with subcutaneous depots to the important visceral depots. An important question is, therefore, whether early growth retardation leads to a persistent modification of insulin action in the deep abdominal adipocyte depots, including mesenteric fat.

The present study examined insulin action with respect to glucose uptake/phosphorylation by adipose tissue in vivo during late pregnancy in adult female rats who had experienced intrauterine and neonatal growth retardation as a consequence of mild maternal protein restriction (the provision of an isoenergetic diet containing $40 \%$ of the standard amount of protein). Glucose uptake/phosphorylation in five white adipose tissue depots was measured in the postabsorptive state and during physiological insulin stimulation using 2-deoxy-D-[1- $\left.{ }^{3} \mathrm{H}\right]$ glucose in combination with the euglycaemic-hyperinsulinaemic clamp. The adipose tissue depots studied included three abdominal depots, one of which was the important mesenteric (visceral) depot, and a superficial depot (subcutaneous) in addition to interscapular adipose tissue. The study of insulin action in the intact animal was then extended by measurements of basal and insulin-stimulated glucose uptake using isolated adipocytes, making comparisons between adipocytes from two distinct abdominal depots, mesenteric and parametrial.

\section{Methods \\ Materials}

Glucose assay kits were obtained from Boehringer Corporation (London), Lewes, Sussex, UK. Kits for determination of plasma insulin concentrations were from Phadeseph Pharmacia, Uppsala, Sweden. Collagenase (EC 3.4.24.3) was purchased from Lorne Laboratories Ltd, Twyford, Berks., UK. Radiolabelled 2-deoxy-D- $\left[1-{ }^{3} \mathrm{H}\right]$ glucose and $\mathrm{D}-\left[\mathrm{U}-{ }^{14} \mathrm{C}\right]$ glucose were purchased from Amersham International, Amersham, Bucks., UK. Other biochemicals and chemicals were from Boehringer Corporation or from Sigma Chemical Corporation, Poole, Dorset, UK. All reagents from commercial sources were of analytical grade.

\section{Diets}

The study utilized diets of the composition and source described in previous studies of the effects of early protein restriction on adult metabolism (Dahri et al. 1991; Sugden \& Holness, 1995; Holness, 1996a,b; Holness \& Sugden, 1996; Shepherd et al. 1997; Holness et al. 1998). Diets were specially prepared in pellet form by Hope Farms BV, Hoge Rijndijk 14, 3440 HD Woerden, The Netherlands. The diets contained either $80 \mathrm{~g}$ protein $/ \mathrm{kg}$ (low-protein diet) or $200 \mathrm{~g}$ protein $/ \mathrm{kg}$ (control diet). It has been demonstrated previously that increased fat consumption leads to the development of insulin resistance (Storlien et al. 1986; Sugden et al. 1996) and therefore both the percentage of fat and the energy density of the two diets were maintained constant. The dietary carbohydrate content was therefore increased to accommodate the decrease in the protein content of the low-protein diet. The control diet contained $(\mathrm{g} / \mathrm{kg})$ : 80 maize starch, 552 cerelose (glucose), 50 cellulose, 43 lipid (soyabean oil) and 200 protein (casein supplemented with DL-methionine). The low-protein diet contained $(\mathrm{g} / \mathrm{kg}): 80$ maize starch, 682 cerelose, 50 cellulose, 43 lipid (soyabean oil) and 80 protein (casein supplemented with DL-methionine). Both diets contained the same salt and vitamin mixture. The energy content (MJ/kg diet) was 15.37 for the $200 \mathrm{~g}$ protein $/ \mathrm{kg}$ diet and 15.28 for the $80 \mathrm{~g}$ protein $/ \mathrm{kg}$ diet.

\section{Experimental groups}

Female Wistar rats (initial weight 200-225 g) were housed in a temperature-controlled room $\left(21 \pm 2^{\circ}\right)$ and were 
subjected to a controlled lighting schedule on a standard $12 \mathrm{~h}$ light-dark cycle (light from 08.00 hours). Firstgeneration rats were time-mated, taking day 0 of gestation as the day on which vaginal plugs were expelled (Lederman \& Rosso, 1981) and then randomly assigned to one of two groups. The first group of dams was maintained throughout pregnancy and lactation on the $200 \mathrm{~g}$ protein $/ \mathrm{kg}$ diet. The second group of dams was maintained throughout pregnancy and lactation on the isoenergetic $80 \mathrm{~g}$ protein $/ \mathrm{kg}$ diet. Spontaneous delivery took place on day 22 or day 23 of pregnancy. The second-generation female offspring of the dams fed on the $200 \mathrm{~g}$ protein $/ \mathrm{kg}$ diet (termed C) and of the $80 \mathrm{~g}$ protein $/ \mathrm{kg}$ diet were weaned at $24 \mathrm{~d}$ on to the $200 \mathrm{~g}$ protein $/ \mathrm{kg}$ diet. After $9-12$ weeks on the $200 \mathrm{~g}$ protein $/ \mathrm{kg}$ diet, the groups of second-generation female offspring were then matched for weight and time-mated. Both groups of second-generation pregnant offspring continued to be maintained on $200 \mathrm{~g}$ protein $/ \mathrm{kg}$ diet throughout gestation, and were studied on day 19 of their own pregnancies. The pregnant offspring of dams maintained on $200 \mathrm{~g}$ protein $/ \mathrm{kg}$ are termed the control (C) group and the pregnant offspring of the first-generation dams maintained on $80 \mathrm{~g}$ protein $/ \mathrm{kg}$ diet are termed the early-protein-restricted (EPR) group. For the in vivo studies, each pregnant rat was fitted with two chronic indwelling jugular cannulas (for infusion and sampling respectively) under Hypnorm and Diazepam anaesthesia between 12 and $14 \mathrm{~d}$ of gestation.

\section{Euglycaemic-hyperinsulinaemic clamp studies}

On the day of the experiment (day 19 of gestation), food was withdrawn at the end of the dark (feeding) phase at 08.00 hours and rats were studied in the post-absorptive state (at $6 \mathrm{~h}$ after food withdrawal) at 14.00 hours. Euglycaemichyperinsulinaemic clamps were performed in awake, unstressed, freely-moving rats. Full details of the procedure are given by Holness (1996b) and Holness \& Sugden (1996). In brief, a primed continuous intravenous infusion of insulin (Human Actrapid, Novo Nordisk, Denmark) was given at a fixed rate of $4.2 \mathrm{mU} / \mathrm{kg}$ body weight per min, selected on the basis of previous studies (Sugden \& Holness, 1995) demonstrating that it produced plasma insulin concentrations in the high physiological range. Insulin infusion was maintained for $2.5 \mathrm{~h}$. A variable rate of glucose infusion was initiated at $1 \mathrm{~min}$ after the start of insulin infusion. Blood was sampled from the right jugular vein at 5-10 min intervals. As pregnancy may alter glucose counter-regulation (Rossi et al. 1993), the glucose infusion rate was adjusted to maintain glycaemia at approximately $4 \mathrm{mM}$ (the concentration found in $19 \mathrm{~d}$-pregnant $\mathrm{C}$ rats in the absorptive state; 4.0 (SE 0.28) mM) in both groups. Steady state was reached after 60-90 min. The CV of blood glucose concentrations during hyperinsulinaemic clamp were less than $12 \%$ in all studies.

\section{In vivo glucose utilization in individual tissues}

Estimations of glucose utilization by individual tissues in vivo were obtained by measuring the accumulation of 2-deoxy-D-[1- $\left.{ }^{3} \mathrm{H}\right]$ glucose 6-phosphate in the tissue after the bolus intravenous injection of tracer amounts $(1 \cdot 11 \mathrm{MBq})$ of the glucose analogue 2-deoxy-D- $\left[1-{ }^{3} \mathrm{H}\right]$ glucose in the basal state or during hyperinsulinaemia (at 90 min after the start of the clamp) (Ferré et al. 1985; Holness \& Sugden, 1990). Blood samples $(100 \mu \mathrm{l})$ for determination of blood glucose concentrations and plasma tracer concentrations were obtained at 1, 3, 5, 10, 20, 40, and $60 \mathrm{~min}$ after 2-deoxy$\mathrm{D}-\left[1-{ }^{3} \mathrm{H}\right]$ glucose bolus administration. Throughout the study, the rats were awake and allowed to move freely, with the connecting tubing suspended overhead. At the end of the 60 min study, a final blood sample $(500 \mu \mathrm{l})$ was added to a heparinized tube, immediately centrifuged at $4^{\circ}$ and plasma was frozen at $-20^{\circ}$ for subsequent insulin determinations. At the time of tissue sampling, blood 2-deoxyD- $\left[1-{ }^{3} \mathrm{H}\right]$ glucose concentration was less than $10 \%$ of the 1 min value. Rats were killed by the intravenous injection of pentobarbitone $(60 \mathrm{mg} / \mathrm{kg})$ via the right jugular cannula. Adipose-tissue samples were freeze-clamped when locomotor activity had ceased (within $5 \mathrm{~s}$ ) and tissues stored in liquid $\mathrm{N}_{2}$ until analysis. The adipose-tissue depots sampled included three abdominal depots, namely the mesenteric (MES), parametrial (PM) and perirenal (PR) depots, and two superficial depots, namely the interscapular (IS) and subcutaneous (SC) depots. IS was differentiated from the interscapular brown adipose tissue depot by visual inspection. MES was freed from lymph nodes by dissection. Some white adipose tissue depots contain small quantities of brown adipose tissue which cannot be discerned by visual inspection and therefore the analysis of the present results does not attempt to ascribe the metabolic responses observed to specific adipocyte types within the predominantly white depots. No correction has been made for possible discrimination against 2-deoxyglucose $v$. glucose with respect to either glucose transport or glucose phosphorylation, and hence rates of tissue accumulation of 2-deoxy-D- $\left[1-{ }^{3} \mathrm{H}\right]$ glucose 6 -phosphate are referred to as glucose utilization index values. The correction factor for the discrimination against 2-deoxyglucose (lumped constant) does not vary with changes in glucose utilization rates in white adipose tissue and thus the use of the glucose utilization index value gives an accurate estimation of differences between groups (Ferré et al. 1985).

\section{Measurements of adipocyte glucose uptake}

Adipocytes were prepared from PM and MES adiposetissue depots, sampled from the same rat, in parallel (see Fryer et al. (1997) for details). All procedures were performed at $37^{\circ}$. Adipocyte sizes were as follows: PM, C group 36.8 (SE 1.3) $\mu \mathrm{m}(n$ 6), EPR group 32.8 (SE 1.0) $\mu \mathrm{m}$ $(n 6)$; MES, C group 29.5 (SE 1.3) $\mu \mathrm{m}(n$ 6), EPR group 26.2 (SE 0.8$) \mu \mathrm{m}(n 6)$. Both sets of adipocytes were resuspended to $20 \%$ lipocrit and portions $(100 \mu \mathrm{l})$ of adipocyte suspension were added to round-bottomed polypropylene tubes containing $0.7 \mathrm{ml}$ HEPES-buffered Krebs-Henseleit saline

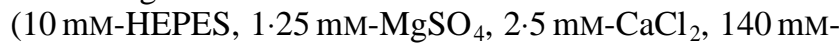
$\mathrm{NaCl}, 2 \mathrm{mM}-\mathrm{K}_{2} \mathrm{HPO}_{4}, 0.5 \mathrm{mM}-\mathrm{KH}_{2} \mathrm{PO}_{4}, \mathrm{pH} 7.4$ ) containing $20 \mathrm{~g}$ bovine serum albumin/l. Adipocyte D-[U- $\left.{ }^{14} \mathrm{C}\right]$ glucose uptake was measured by a modification of the method described by Kashiwagi et al. (1983). Adipocytes were preincubated for $30 \mathrm{~min}$ (200 oscillations/min) in $500 \mu \mathrm{l}$ HEPES-buffered Krebs-Henseleit saline containing $20 \mathrm{~g}$ 


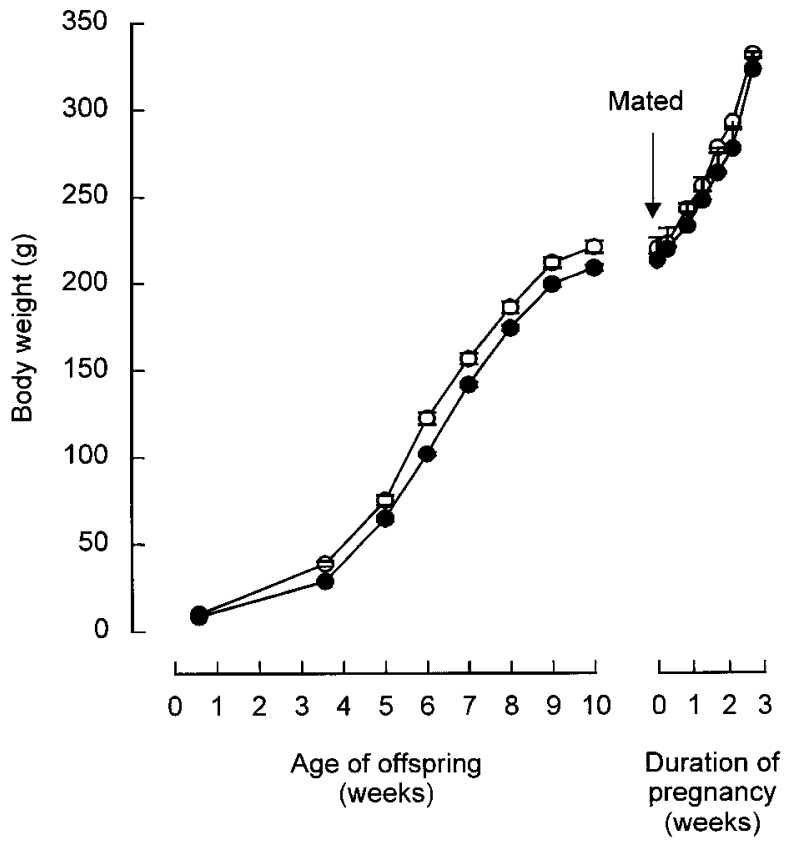

Fig. 1. Body weights of offspring of dams provided with diets containing either $200 \mathrm{~g}$ protein $/ \mathrm{kg}$ (control group, O) or $80 \mathrm{~g}$ protein $/ \mathrm{kg}$ (earlyprotein-restricted group, $\bullet$ ) throughout pregnancy and lactation. Both groups of offspring were transferred to the diet containing $200 \mathrm{~g}$ protein $/ \mathrm{kg}$ at weaning. Values are means for eight to ten female animals per group (from six litters per group) with their standard errors represented by vertical bars. In some cases, standard errors have been obscured by the symbols.

bovine serum albumin/l in the absence or presence of insulin at the concentrations indicated. Total preincubation volume was $500 \mu \mathrm{l}$. Following the addition of D-[U- $\left.{ }^{14} \mathrm{C}\right]$ glucose $(1.85 \mathrm{kBq}$ to a final concentration of $300 \mathrm{nM})$, adipocytes were incubated for a further $60 \mathrm{~min}$ in a shaking water bath at $200 \mathrm{strokes} / \mathrm{min}$. Glucose uptake was terminated by centrifugation $(10000 \mathrm{~g}, 30 \mathrm{~s})$ of a $300 \mu \mathrm{l}$ portion through $100 \mu \mathrm{l}$ silicone oil (density $0.97 \mathrm{~g} / \mathrm{ml}$ ). After centrifugation, microfuge tubes were cut through the oil layer and the upper portion, containing packed adipocytes, was placed into $10 \mathrm{ml}$ scintillation fluid and counted for ${ }^{14} \mathrm{C}$. Glucose uptake was calculated from the specific activity of $\mathrm{D}-\left[\mathrm{U}-{ }^{14} \mathrm{C}\right] \mathrm{glucose}$, the packed cell volume and cell size.

\section{Analytical methods}

Blood glucose concentrations during the clamps were determined using a glucose analyser (YSI, Yellow Springs,
$\mathrm{OH}$, USA). Blood samples for determination of tracer concentrations were deproteinized immediately with $\mathrm{ZnSO}_{4} /$ $\mathrm{Ba}(\mathrm{OH})_{2}$ and immediately centrifuged. A portion of the supernatant fraction was added to scintillant (Optiphase HiSafe 3) for counting in a liquid scintillation counter. Plasma insulin was measured with a radioimmunoassay kit, using rat insulin standards.

\section{Statistical analysis}

Experimental data are expressed as means with their standard errors, with the numbers of observations (individual rats or adipocyte preparations) in parentheses. Statistical significance of differences was assessed by ANOVA followed by individual comparisons by Fisher post hoc tests using software (Statview) from Abacus Concepts, Inc., Berkeley, CA, USA. An absolute probability $(P)$ value of $<0.05$ was considered to be statistically significant.

\section{Results}

Animal growth

At weaning body weights of the offspring of the firstgeneration dams maintained on $80 \mathrm{~g}$ protein $/ \mathrm{kg}$ diet (EPR group) were $79 \%(P<0 \cdot 01)$ of those of the second-generation offspring of dams maintained on $200 \mathrm{~g}$ protein $/ \mathrm{kg}$ diet (C group). Growth curves for the two groups of rats subsequent to weaning until mating are shown in Fig. 1. At the time of mating, the body weights of the EPR offspring were approximately $5 \%$ lower $(P<0.05)$ than those of the $\mathrm{C}$ group. Neither the food intake nor the bodyweight gain of the second-generation offspring during pregnancy was influenced by exposure to maternal low $(80 \mathrm{~g} / \mathrm{kg})$-protein diet during fetal development and suckling (results not shown; see also Holness \& Sugden, 1996). In the two groups studied, body weights at day 19 of gestation were 324 (SE 7) $g(n$ 12) for the C pregnant group and 327 (SE 5) $\mathrm{g}(n$ ) ) for the EPR pregnant group.

\section{Glucose utilization in the post-absorptive state}

Blood glucose and plasma insulin concentrations in the post-absorptive state were similar in the $\mathrm{C}$ and EPR pregnant groups (Table 1). Rates of glucose utilization (transport + phosphorylation) in vivo (estimated from 2-deoxy-D$\left[1-{ }^{3} \mathrm{H}\right]$ glucose 6-phosphate accumulation) are shown for PM, PR, SC, IS and MES adipose-tissue depots of the

Table 1. Blood glucose and plasma insulin concentrations in the post-absorptive state and during hyperinsulinaemia in 19-d-pregnant offspring of dams provided with diets containing either $200 \mathrm{~g}$ protein $/ \mathrm{kg}(\mathrm{C})$ or $80 \mathrm{~g}$ protein $/ \mathrm{kg}$ (EPR) during pregnancy and lactation*

(Mean values with their standard errors for eleven to twenty animals per group)

\begin{tabular}{|c|c|c|c|c|c|c|c|c|}
\hline & \multicolumn{4}{|c|}{ Post-absorptive } & \multicolumn{4}{|c|}{ Steady-state hyperinsulinaemia } \\
\hline & \multicolumn{2}{|c|}{ C } & \multicolumn{2}{|c|}{ EPR } & \multicolumn{2}{|c|}{$\mathrm{C}$} & \multicolumn{2}{|c|}{ EPR } \\
\hline & Mean & SE & Mean & $\overline{\mathrm{SE}}$ & Mean & $\overline{\mathrm{SE}}$ & Mean & SE \\
\hline Blood glucose $(\mathrm{mmol} / \mathrm{l})$ & 3.0 & 0.1 & $3 \cdot 2$ & 0.1 & $4 \cdot 1$ & 0.1 & 3.8 & 0.1 \\
\hline Plasma insulin $(\mu \mathrm{U} / \mathrm{ml})$ & 9 & 1 & 10 & 1 & 82 & 8 & 87 & 9 \\
\hline
\end{tabular}

${ }^{*}$ For details of diets and procedures, see pp. 482-484. 


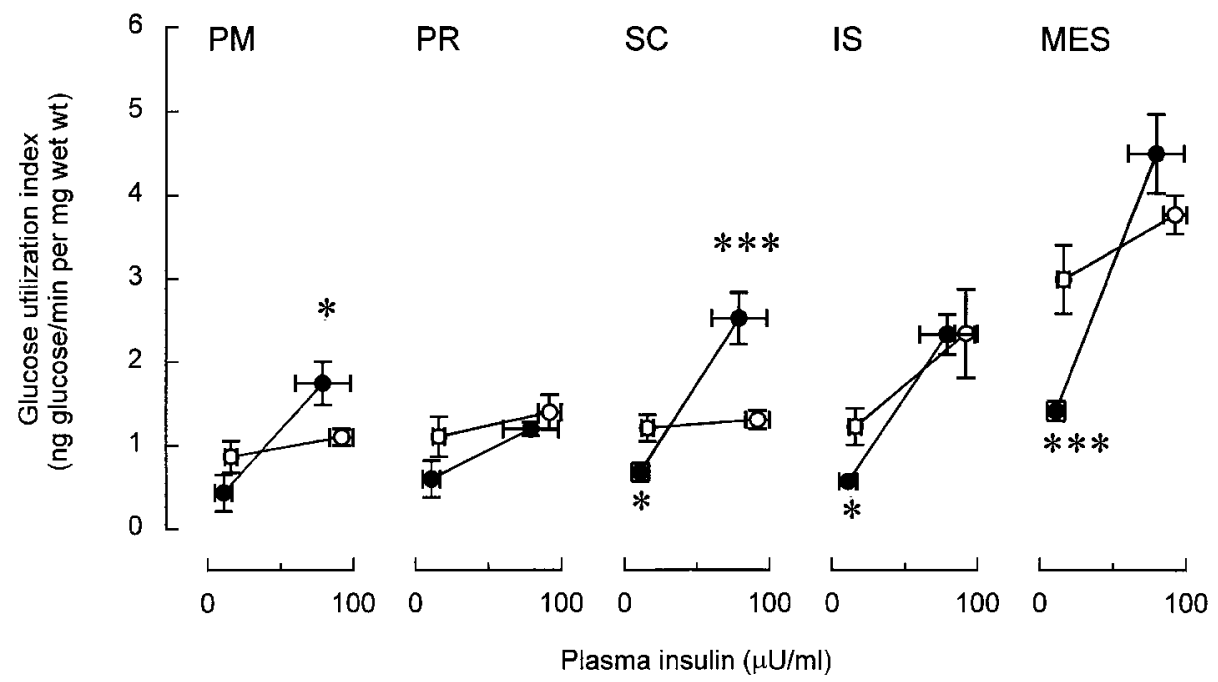

Fig. 2. Rates of glucose utilization in vivo (estimated from 2-deoxy-D-[1- $\left.{ }^{3} \mathrm{H}\right]$ glucose 6 -phosphate accumulation) in parametrial (PM), perirenal (PR), subcutaneous (SC), interscapular (IS) and mesenteric (MES) adipose-tissue depots of 19-d-pregnant offspring of dams provided with diets containing either $200 \mathrm{~g}$ protein $/ \mathrm{kg}$ (control group, O) or $80 \mathrm{~g}$ protein $/ \mathrm{kg}$ (early-protein-restricted group, ๑) throughout pregnancy and lactation. Rates of glucose utilization (glucose utilization indices) were measured in the basal state or after euglycaemic-hyperinsulinaemic clamps. Values are means for seven to ten female animals per group (from six litters per group) with their standard errors represented by vertical and horizontal bars. Mean values were significantly different from those for the control group: ${ }^{*} P<0.05,{ }^{* \star} P<0.01,{ }^{\star \star *} P<0.001$.

19-d-pregnant rats in Fig. 2. In the $\mathrm{C}$ pregnant group, glucose utilization rates in the post-absorptive state showed no statistically significant variation between the PM, PR, SC and IS depots; however, glucose utilization by the MES depot was significantly (approximately $2 \cdot 5-$ to 3.0-fold, $P<0.001$ ) higher than in the other four depots. Rates of glucose utilization by adipose tissue in the postabsorptive state in vivo were consistently lower (by 44$53 \%$ ) in the pregnant rats that had experienced early growth retardation than in the $\mathrm{C}$ pregnant group, with significant effects of early protein restriction in the SC, IS and MES depots (Fig. 2). As in the $\mathrm{C}$ pregnant group, there was no statistically significant variation in basal glucose utilization rates between depots in the EPR pregnant group, with the exception of the MES depot which exhibited rates of glucose utilization that were approximately 2-fold higher $(P<0 \cdot 01)$ than those of the other adipose-tissue depots.

\section{Characteristics of glucose utilization (transport + phosphorylation) by individual adipocyte depots in the intact animal during hyperinsulinaemia}

Insulin was infused at a fixed rate to obtain steady-state insulin concentrations in the high physiological range (approximately 80-90 $\mu \mathrm{U} / \mathrm{ml}$ plasma), comparable to the concentrations found after an intravenous glucose load in late pregnancy (Holness \& Sugden, 1996). Steady-state plasma insulin and glucose concentrations during the infusions are shown in Table 1 . In the $\mathrm{C}$ pregnant group, the only adipocyte depot exhibiting a significant increase in glucose utilization rate in vivo in response to hyperinsulinaemia was the IS depot (2.3-fold; $P<0.05)$; a trend towards increased glucose utilization during hyperinsulinaemia was also evident in the MES depot, although this did not achieve statistical significance (Fig. 2). In contrast, marked and significant increases in glucose utilization rates in response to hyperinsulinaemia were evident in all of the adiposetissue depots of the pregnant rats that had experienced early protein restriction. The increases in glucose utilization elicited by hyperinsulinaemia were $2 \cdot 0$-fold $(P<0 \cdot 001)$ in MES, 3.2-fold $(P<0.01)$ in IS, 3.8-fold $(P<0.05)$ in PR, $4 \cdot 1$-fold $(P<0.001)$ in PM and $4 \cdot 2$-fold $(P<0.001)$ in SC depots. In three of the five depots (PR, IS and MES), the approximate doubling of the response to insulin in the EPR pregnant group resulted in normalization of rates of glucose utilization between the $\mathrm{C}$ and $\mathrm{EPR}$ pregnant groups. In the other two depots (PM and SC), glucose utilization rates during hyperinsulinaemia were significantly higher (by 1.6to 1.9 -fold) in the pregnant rats that had experienced early protein restriction.

\section{Characteristics of basal and insulin-stimulated glucose uptake in mesenteric and parametrial adipocytes from pregnant rats}

Adipocytes were isolated from two abdominal adiposetissue depots (PM and MES) to determine whether differences in the responses to insulin in vivo were retained in vitro. The effects of insulin on adipocyte glucose uptake were investigated at three insulin concentrations, namely $0 \cdot 1 \mu \mathrm{U} / \mathrm{ml}$ (basal), $15 \mu \mathrm{U} / \mathrm{ml}$ (low physiological range) and $15000 \mu \mathrm{U} / \mathrm{ml}$ (supraphysiological range). With regard to basal glucose uptake, adipocytes as prepared generally retain bound insulin and, although cells were preincubated, this cannot be quantified. The addition of $0 \cdot 1 \mu \mathrm{U}$ insulin $/ \mathrm{ml}$ overcomes the possibility of variable (but very small) amounts of bound insulin between groups. In the $\mathrm{C}$ pregnant group, basal rates of glucose uptake were similar in MES and PM adipocytes. Basal rates of glucose uptake by cells from the two depots were not statistically affected by early protein restriction. However, insulin at the maximal concentration $(15000 \mu \mathrm{U} / \mathrm{ml})$ 
Table 2. Effects of insulin on rates of glucose uptake ( $\mathrm{fmol} / \mathrm{h}$ per cell) in mesenteric and parametrial adipocytes prepared from 19-d-pregnant offspring of dams provided with diets containing either $200 \mathrm{~g}$ protein $/ \mathrm{kg}(\mathrm{C})$ or $80 \mathrm{~g} \mathrm{protein} / \mathrm{kg}$ (EPR) during pregnancy and lactation†

(Mean values with their standard errors for six animals per group)

\begin{tabular}{|c|c|c|c|c|c|c|c|c|}
\hline & \multicolumn{4}{|c|}{ Mesenteric } & \multicolumn{4}{|c|}{ Parametrial } \\
\hline & \multicolumn{2}{|c|}{ C } & \multicolumn{2}{|c|}{ EPR } & \multicolumn{2}{|c|}{ C } & \multicolumn{2}{|c|}{ EPR } \\
\hline & Mean & SE & Mean & SE & Mean & SE & Mean & SE \\
\hline \multicolumn{9}{|c|}{ Insulin $(\mu \mathrm{U} / \mathrm{ml})$} \\
\hline 0.1 & 0.011 & 0.003 & 0.014 & 0.003 & 0.006 & 0.001 & 0.008 & 0.001 \\
\hline 15 & 0.038 & 0.005 & $0.230^{* * *}$ & 0.047 & 0.022 & 0.003 & $0.092^{*}$ & 0.023 \\
\hline 15000 & 0.059 & 0.009 & $0.306^{* * *}$ & 0.050 & 0.044 & 0.011 & $0.211^{* * *}$ & 0.055 \\
\hline
\end{tabular}

Mean values were significantly different from those for the $C$ group: ${ }^{*} P<0.05,{ }^{* * *} P<0.001$.

$\dagger$ For details of diets and procedures, see pp. 482-484.

evoked considerably larger increases in rates of glucose uptake in adipocytes prepared from the EPR pregnant group (Table 2). The enhanced response to insulin was apparent with adipocytes from both depots, with 22-fold stimulation in MES (compared with 5-fold stimulation with cells from the $\mathrm{C}$ pregnant group) and 26-fold stimulation in PM (compared with 7.3-fold stimulation with cells from the $\mathrm{C}$ pregnant group). As a consequence, maximal rates of glucose uptake with cells from the EPR pregnant rat group were 5.2-fold higher $(P<0.001)$ than control in MES adipocytes, and $4 \cdot 8$-fold higher $(P<0.001)$ than control in PM adipocytes. Increased rates of insulin-stimulated glucose uptake were also observed at the sub-maximal insulin concentration of $15 \mu \mathrm{U} / \mathrm{ml}$; however, the effect of early protein restriction to enhance insulin-stimulated glucose uptake was more marked in MES adipocytes (6.1-fold; $P<0.001)$ than in PM adipocytes (4.2-fold; $P<0.05$ ).
The effect of early protein restriction on the insulin sensitivity of glucose uptake with mesenteric and parametrial adipocytes from pregnant rats

Dose-response curves for stimulation of glucose uptake by insulin are shown in Fig. 3. Analysis of the dose-response data indicated that, with cells from $\mathrm{C}$ pregnant rats, an insulin concentration of $75 \mu \mathrm{U} / \mathrm{ml}$ elicited $80-90 \%$ of the maximal response. At an insulin concentration of $15 \mu \mathrm{U} / \mathrm{ml}$ (approximating to that found in the post-absorptive state in vivo), stimulation of glucose uptake was $72 \%$ of maximal for MES adipocytes and $58 \%$ of maximal for PM adipocytes. The threshold concentration for a significant effect of insulin was $10 \mu \mathrm{U} / \mathrm{ml}$ in MES $(P<0.01)$ and $15 \mu \mathrm{U} / \mathrm{ml}$ in PM $(P<0 \cdot 001)$. The sensitivity of glucose uptake to stimulation by insulin is thus greater for MES than for PM. The percentage stimulation of glucose uptake by insulin was
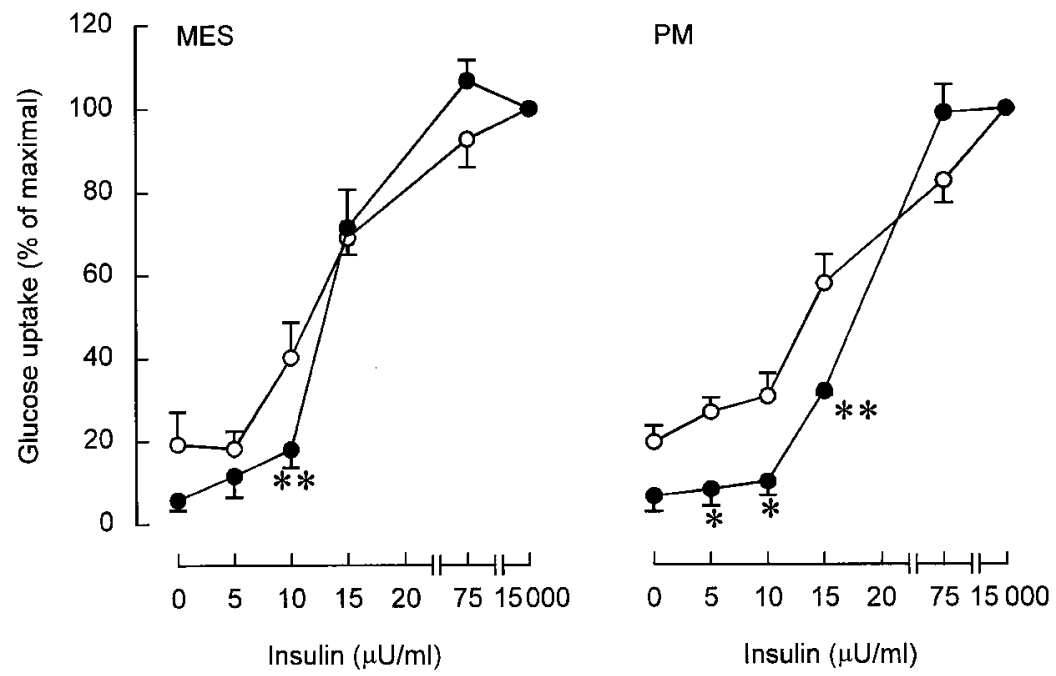

Fig. 3. Effects of insulin on glucose uptake into freshly isolated mesenteric (MES) and parametrial (PM) adipocytes from 19-d-pregnant offspring of dams provided with diets containing either $200 \mathrm{~g}$ protein $/ \mathrm{kg}$ (control group, O) or $80 \mathrm{~g}$ protein $/ \mathrm{kg}$ (early-proteinrestricted group, $\bullet$ ) throughout pregnancy and lactation. Adipocyte D-[U- $\left.{ }^{14} \mathrm{C}\right] \mathrm{glucose}$ uptake was measured by a modification of the method described in Kashiwagi et al. (1983) and is expressed as a percentage of the maximal rate of glucose uptake. Values are means for five or six female animals per group (from four litters per group) with their standard errors represented by vertical bars. Mean values were significantly different from those for the control group: ${ }^{*} P<0.05,{ }^{*} P<0.01$. 
suppressed by early protein restriction in PM (at 5, 10 and $15 \mu \mathrm{U}$ insulin/ml) and in MES (at $10 \mu \mathrm{U}$ insulin/ml). However, there was no impairment in the response of glucose uptake (expressed as a percentage of the maximal rate) to insulin at a physiologically high concentration $(75 \mu \mathrm{U} / \mathrm{ml})$ in adipocytes from either depot as a consequence of early protein restriction. Thus, a rise in insulin concentration from $10 \mu \mathrm{U} / \mathrm{ml}$ to $75 \mu \mathrm{U} / \mathrm{ml}$ was associated with a greater response of glucose uptake in both MES and PM adipocytes from the EPR pregnant group compared with the $\mathrm{C}$ pregnant group.

\section{Discussion}

The objectives of the study were first, to examine the effects of hyperinsulinaemia on adipocyte glucose utilization in vivo during pregnancy to establish whether variability exists between the responses of different white adipose tissue depots; second, to determine whether early protein restriction during fetal and early neonatal life has a persistent influence on the response of adipose-tissue glucose utilization to insulin in vivo during pregnancy; and third, to examine whether differences observed in the intact pregnant animal are evident with isolated adipocytes, implying a stable effect independent of the prevailing hormonal and metabolic milieu. We focused on the long-term effects of poor nutrition using a rat model where rat dams are provided with either a low $(80 \mathrm{~g} / \mathrm{kg})$ protein or a control $(200 \mathrm{~g} / \mathrm{kg})$ diet during pregnancy and lactation. We have shown previously using the same model that growth retardation evoked by suboptimal protein restriction during early life leads to decreased basal glucose turnover and glucose utilization in a range of maternal tissues and the fetus during a subsequent pregnancy in the absence of any consistent impairment of insulin-stimulated glucose disposal (Holness \& Sugden, 1996). The results of the current study reveal that there are important persistent effects of early protein restriction on the characteristics of adipocyte glucose uptake which are evident both in vitro and in the intact animal during a subsequent pregnancy. In the $\mathrm{C}$ pregnant group, increasing the insulin concentration from post-absorptive levels to the high physiological range (approximately $80-90 \mu \mathrm{U} / \mathrm{ml}$ ) increased glucose utilization significantly only in one of five depots (IS). This finding was not entirely unexpected as insulin resistance in adipose tissue of pregnant rats in vivo has been reported previously (Leturque et al. 1984, 1986). However, insulin markedly stimulated glucose utilization in vitro in adipocytes from two distinct depots (MES and PM). Analysis of the doseresponse curve indicates that glucose utilization is sensitive to stimulation by insulin in the range of concentrations that prevail in the $6 \mathrm{~h}$ post-absorptive state. The failure to observe marked effects of hyperinsulinaemia to stimulate glucose uptake and phosphorylation in vivo may therefore be a consequence of the sensitivity of the response of adipocyte glucose uptake to insulin. We examined the issue of site-specific properties of MES $v$. PM abdominal adipocytes in late pregnancy in relation to the characteristics of glucose uptake using PM and MES adipocyte preparations from the same animal and subsequently incubating the cells in parallel under identical conditions. The in vitro data indicate that, during a normal pregnancy, MES is characterized by greater sensitivity of glucose uptake to stimulation by insulin than PM. In adipose tissue, glucose subserves an important function as a precursor for glycerol 3-phosphate synthesis as well as for fatty acid synthesis. The in vivo and in vitro findings are therefore consistent with the concept of MES as an important site of triacylglycerol storage during pregnancy.

We observed consistent suppression of glucose uptake in the post-absorptive state by three out of the five adiposetissue depots examined as a result of early protein restriction, even though the rats had been switched to a diet containing the standard amount of protein $(200 \mathrm{~g} / \mathrm{kg})$ at weaning and maintained on the standard protein diet throughout adulthood. This persistent effect of early protein restriction was particularly significant in MES. Results obtained at sub-maximal insulin concentrations revealed an effect of early protein restriction to impair stimulation of glucose uptake in MES adipocytes. These in vitro results reiterate the studies demonstrating suppression of glucose uptake and phosphorylation by MES in the post-absorptive state in vivo, and indicate a stable change in the properties of adipocyte glucose uptake that is retained ex vivo. The apparently contradictory findings of reduced absolute rates of glucose uptake by adipose tissue in the basal state in EPR rats in vivo, but markedly increased glucose uptake rates in adipocytes prepared from EPR rats and incubated in vitro at low insulin concentrations presumably reflects circulating factors that are lost in vitro. In this regard, previous studies by Leturque et al. (1984) have demonstrated that the adipocyte insulin resistance in terms of glucose uptake/ phosphorylation observed in vivo during late pregnancy is not retained in adipocyte preparations.

We explored the possibility of differential effects of early protein restriction on insulin action at the level of glucose uptake in the MES and PM adipose-tissue depots. The findings with isolated adipocytes show some evidence for the existence of inter-depot variation in terms of the sensitivity of glucose uptake to insulin at low concentrations. There is a trend towards a more significant impact of early protein restriction in the PM depot. On the basis of the results in vivo and in vitro, it would be predicted that glucose uptake in most white adipose-tissue depots in EPR rats would be relatively insensitive to the changes in insulin concentrations in the low physiological range, such as are observed, for example, during the initial period over which insulin secretion is established after re-feeding.

Enhanced rates of glucose uptake at high insulin concentrations have been demonstrated previously using adipocytes isolated from epididymal fat pads of male rats that had experienced protein restriction during early life (Ozanne et al. 1997). These changes were observed in association with a 2-fold increase in insulin receptor levels, but no change in glucose transporter-4 expression (Shepherd et al. 1997). Our study with isolated abdominal adipocytes demonstrates that an effect of early protein restriction to increase the capacity for insulin-stimulated glucose utilization in vitro is not exclusive to males and, remarkably, is retained despite the marked changes in hormonal milieu and metabolic demands associated with gestation. Our data further demonstrate that the effect of 
protein restriction to enhance glucose uptake at maximal insulin concentrations is evident in adipocytes from two metabolically-distinct abdominal white adipose-tissue depots, with a striking similarity in the magnitude of the augmented response (approximately 3-fold). The results with isolated adipocytes support our studies in vivo using the euglycaemic-hyperinsulinaemic clamp demonstrating lower basal glucose utilization but an enhanced response of glucose utilization to insulin when insulin is elevated to concentrations in the high physiological range. Therefore, it appears that metabolic programming of the capacity for white adipocyte glucose uptake by early protein restriction is fundamental to the glucoregulatory modifications associated with this model.

In summary, the present results demonstrate that while the overall effect of early protein restriction is to enhance the overall capacity for glucose uptake at high insulin concentrations, excursions in rates of glucose uptake are dampened when insulin concentrations are varied in the low physiological range (i.e. the threshold for the effect of insulin is increased). Although the contribution of white adipose tissue to peripheral insulin-stimulated glucose disposal in the non-obese rat is not great $(<10 \%$; Ferré et al. 1985), the ability to enhance glucose uptake in response to hyperinsulinaemia is essential for the esterification of fatty acids (derived either from circulating lipoproteins or via endogenous fatty acid synthesis). Thus, the exaggeration of the changes in glucose uptake elicited by a modest fall in insulin might be predicted to favour accelerated triacylglycerol lipolysis after food withdrawal. Furthermore, the inability to rapidly increase glucose uptake in response to a modest rise in insulin in the EPR rats may be associated with reduced esterification of fatty acids, and therefore decreased fat deposition.

\section{Acknowledgements}

We thank the Medical Research Council and the British Diabetic Association for support.

\section{References}

Barker DJP, Godfrey KM, Osmond C \& Bull A (1992) The relation of fetal length, ponderal index and head circumference to blood pressure and the risk of hypertension in adult life. Paediatric and Perinatal Epidemiology 6, 35-44.

Bjorntorp P (1990) "Portal" adipose tissue as a generator of risk factors for cardiovascular disease and diabetes. Atherosclerosis 10, 493-496.

Bolinder J, Kager L, Ostman J \& Arner P (1983) Differences at the receptor and postreceptor levels between human omental and subcutaneous adipose tissue in the action of insulin on lipolysis. Diabetes 32, 117-123.

Carey DG, Jenkins AB, Campbell LV, Freund J \& Chisholm DJ (1996) Abdominal fat and insulin resistance in normal and overweight women: direct measurements reveal a strong relationship in subjects at both low and high risk of NIDDM. Diabetes 45, 633-638.

Colberg SR, Simoneau JA, Thaete FL \& Kelley DE (1995) Skeletal muscle utilization of free fatty acids in women with visceral obesity. Journal of Clinical Investigation 95, 1846-1853.

Coon PJ, Rogus EM, Drinkwater D, Muller DC \& Goldberg AP (1992) Role of body fat distribution in the decline in insulin sensitivity and glucose tolerance with age. Journal of Clinical Endocrinology and Metabolism 75, 1125-1132.

Dahri S, Snoeck A, Reusens-Billen B, Remacle C \& Hoet JJ (1991) Islet function in offspring of mothers on low-protein diet during gestation. Diabetes 40, 115-120.

Desai M, Byrne CD, Meeran K, Martenz ND, Bloom SR \& Hales CN (1997) Regulation of hepatic enzymes and insulin levels in offspring of rat dams fed a reduced-protein diet. American Journal of Physiology 273, G899-G904.

Engfeldt P \& Arner P (1988) Lipolysis in human adipocytes, effects of cell size, age and of regional differences. Hormone and Metabolic Research 19, 26-29.

Ferré P, Leturque A, Burnol A-F, Pénicaud L \& Girard J (1985) A method to quantify glucose utilization in vivo in skeletal muscle and white adipose tissue of the anaesthetized rat. Biochemical Journal 228, 103-110.

Fryer LGD, Holness MJ \& Sugden MC (1997) Selective modification of insulin action in adipose tissue by hyperthyroidism. Journal of Endocrinology 154, 513-522.

Hales CN (1997) Fetal and infant growth and impaired glucose tolerance in adulthood: the "thrifty phenotype" hypothesis revisited. Acta Paediatrica 422, Suppl., 73-77.

Holness MJ (1996a) The influence of sub-optimal protein nutrition on insulin hypersecretion evoked by high-energy/high-fat feeding in rats. FEBS Letters 396, 53-56.

Holness MJ (1996b) The impact of early growth retardation on glucoregulatory control and insulin action in mature rats. American Journal of Physiology 270, E946-E954.

Holness MJ, Priestman DA \& Sugden MC (1998) Impact of protein restriction on the regulation of cardiac carnitine palmitoyltransferase by malonyl-CoA. Journal of Molecular and Cellular Cardiology 30, 1381-1390.

Holness MJ \& Sugden MC (1990) Glucose utilization in heart, diaphragm and skeletal muscle during the fed-to-starved transition. Biochemical Journal 220, 245-249.

Holness MJ \& Sugden MC (1996) Suboptimal protein nutrition in early life later influences insulin action in pregnant rats. Diabetologia 39, 12-21.

Holness MJ \& Sugden MC (1997) Glucoregulation during progressive starvation in late pregnancy in the rat. American Journal of Physiology 272, E556-E561.

Kashiwagi A, Verso MA, Andrews J, Vasquez B, Reaven G \& Foley JE (1983) In vitro resistance of human adipocytes isolated from subjects with non-insulin dependent diabetes mellitus. Journal of Clinical Investigation 72, 1246-1254.

Langley-Evans SC, Welham SJ, Sherman RC \& Jackson AA (1996) Weanling rats exposed to maternal low-protein diets during discrete periods of gestation exhibit differing severity of hypertension. Clinical Science 91, 607-615.

Lederman S \& Rosso P (1981) Effects of fasting during pregnancy on maternal and fetal weight and body composition in wellnourished and undernourished rats. Journal of Nutrition 111, 1823-1832.

Leturque A, Guerre-Millo M, Lavau M \& Girard J (1984) Effects of insulin on glucose metabolism in adipocytes from virgin and late-pregnant rats. Biochemical Journal 224, 685-688.

Leturque A, Ferré P, Burnol A-F, Kandé J, Maulard P \& Girard J (1986) Glucose utilization rates and insulin sensitivity in vivo in tissues of virgin and pregnant rats. Diabetes 35, 172-177.

Nolan CJ \& Proietto J (1996) The setpoint for maternal glucose homeostasis is lowered during late pregnancy in the rat: the role of the islet beta-cell and liver. Diabetologia 39, 785-792.

Ostman J, Arner P, Engfeldt P \& Kager L (1979) Regional differences in the control of lipolysis in human adipose tissue. Metabolism 28, 1198-1205.

Ozanne SE, Nave BT, Wang CL, Shepherd PR, Prins J \& Smith GD (1997) Poor fetal nutrition causes long-term changes in 
expression of insulin signaling components in adipocytes. American Journal of Physiology 273, E46-E51.

Peiris AN, Struve MF, Mueller RA, Lee MB \& Kissebah AH (1988) Glucose metabolism in obesity: influence of body fat distribution. Journal of Clinical Endocrinology and Metabolism 67, 760-767.

Rossi G, Lapaczewski P, Diamond MP, Jacob RJ, Shulman GI \& Sherwin RS (1993) Inhibitory effect of pregnancy on counterregulatory hormone responses to hypoglycemia in awake rat. Diabetes 42, 1440-1445.

Shepherd PR, Crowther NJ, Desai M, Hales CN \& Ozanne SE (1997) Altered adipocyte properties in the offspring of protein malnourished rats. British Journal of Nutrition 78, 121-129.

Storlien LH, James DE, Burleigh KM, Chisholm DJ \& Kraegen EW (1986) Fat feeding causes widespread in vivo insulin resistance, decreased energy expenditure, and obesity in rats. American Journal of Physiology 251, E576-E583.

Sugden MC, Fryer LGD \& Holness MJ (1996) Regulation of hepatic pyruvate dehydrogenase kinase by insulin and dietary manipulation in vivo. Studies with the euglycaemic-hyperinsulinaemic clamp. Biochimica et Biophysica Acta 1316, 114-120.

Sugden MC \& Holness MJ (1995) Modulation of in vivo insulin action by dietary protein during pregnancy. American Journal of Physiology 268, E722-E729.

Sugden MC \& Holness MJ (1998) Fuel selection: the maternal adaptation to fetal nutrient demand. Biochemical Society Transactions 26, 79-86.

West DB, Prinz WA \& Greenwood MRC (1989) Regional changes in adipose tissue blood flow and metabolism after a meal. American Journal of Physiology 257, R711-R716. 